\title{
Appreciation of RMB Exchange Rate and its Impact on China's Foreign Trade
}

\author{
Xindi Wang ${ }^{1, ~ a ~}$, Xin Jin $^{2, b}$ \\ ${ }^{1}$ School of Economics and Management, Beijing Jiaotong University, Beijing 100044, China \\ ${ }^{2}$ School of Economics and Management, Beijing Jiaotong University, Beijing 100044, China \\ axdwang@bjtu.edu.cn, ${ }^{b} 526684517 @ q q . c o m$
}

Keywords: RMB appreciation; import and export trade; foreign trade dependence

Abstract: This paper, first researches the reform course and status quo of RMB exchange rate. Then, it makes an empirical study by using the relevant data of RMB exchange rate and foreign trade from 2006 to 2017, summarizes the reasons for RMB appreciation and expounds the positive and negative effects of RMB appreciation on China's foreign trade from three aspects: total volume, foreign trade dependence and trade mode. Finally, it puts forward some suggestions on the adverse effects in order to provide decision-making reference for macroeconomic management departments and better adjust the fluctuation of the RMB exchange rate.

\section{Introduction}

With the deepening of world economic integration and liberalization of international trade as well as China's reform and opening up, China's economy has always maintained a strong momentum of development. At the same time, facing with the dilemma of international economic downturn, many countries attributed the slow economic development to the underestimate of the RMB exchange rate and put pressure on our country to ask for RMB appreciation. Faced with the above challenges, China began to implement a managed floating exchange rate system with reference to a basket of currencies since July 21, 2005.This reform brings both opportunities and challenges to China's foreign trade and economic development. Through theoretical and empirical analysis, we can more intuitively understand the impact of RMB appreciation on economic growth and its extent, and thus put forward targeted suggestions to promote its positive role in macroeconomic development.[1]

\section{Reform Course and Reason Analysis}

\subsection{Reform course and its characteristic}

The reform course of RMB exchange rate system can be mainly divided into three parts, as shown in Table 1. 
Table 1 Reform course of RMB exchange rate system

\begin{tabular}{|c|c|}
\hline Stage & RMB exchange rate system \\
\hline $1985-1993$ & Double exchange rate system \\
\hline 1994-2005.6 & Managed floating exchange rate system \\
\hline 2005.7-today & Managed floating exchange rate system reference to a basket of currencies \\
\hline
\end{tabular}

Since the exchange rate reform in 2005, the RMB exchange rate has maintained a sustained and stable growth. The appreciation of the RMB exchange rate can be roughly divided into the following 4 stages, as shown in Table 2.[2]

Table 2 RMB appreciation process

\begin{tabular}{|c|c|c|}
\hline Stage & Time & The Characteristic of RMB appreciation process \\
\hline 1 & $2005,7-2006,4$ & Rose steadily \\
\hline 2 & $2006,5-2008,8$ & Apparent acceleration, the appreciation has has been over \\
$15 \%$.
\end{tabular}

\subsection{The reason for $\mathrm{RMB}$ appreciation}

Since the reform in 2005, the RMB exchange rate has been showing a steady and appreciating trend. The main reasons are analyzed in the following two aspects.

\subsubsection{The sustained and high speed growth of China's economy}

In recent years, China's economy is continuing to grow rapidly, the momentum of development is strong and a large number of exports have attracted the increase of foreign investment, which makes the domestic and foreign market demand for RMB become particularly strong. Even though China was once affected by the international financial crisis and other factors, China has maintained a relatively rapid economic growth rate. During the ten years from 2006 to 2015, China's economic growth rate fluctuated at around 10\%[3].In the long run, the rapid growth of China's economy will inevitably lead to the rise of the RMB exchange rate.

\subsubsection{The gradually expanding balance of payments surplus}

The foreign exchange supply and demand of a country depends on its balance of payments. Therefore, the balance of payments situation has become a key factor affecting the exchange rate changes. In a certain period of time, when a country's foreign exchange inflow is greater than outflow, the country's balance of payments trade surplus occurs, which makes the country's demand for domestic currency becomes particularly strong which led to the continuous appreciation of the currency. [4]China's balance of payments has been in a trade surplus for a long time, and the supply of foreign exchange is far greater than the demand for foreign exchange, which also contributes to the continued high operation of the RMB.

\section{The Impact on China's Foreign Trade}

\subsection{China's foreign trade development}

\subsubsection{Changes in the trade volume}

RMB has continued to appreciate since China's exchange rate reform in 2005, and the transaction 
price of US dollar to RMB has risen from 1:8.11 in 2005 to 1:6.5 in 2015. During this period, a series of changes have taken place in China's foreign trade.

Table 3 Percentage change of major foreign trade data in China between 2006 to 2015

\begin{tabular}{|c|c|c|c|c|}
\hline Year & $\begin{array}{l}\text { Increase in import } \\
\text { and export volume }\end{array}$ & Import growth & Export growth & $\begin{array}{l}\text { Increase in trade } \\
\text { surplus }\end{array}$ \\
\hline 2006 & 24.1 & 19.9 & 26.8 & 73.9 \\
\hline 2007 & 23.5 & 20.8 & 25.7 & 47.7 \\
\hline 2008 & 17.8 & 18.5 & 17.2 & 12.7 \\
\hline 2009 & -13.9 & -11.2 & -16.0 & -33.6 \\
\hline 2010 & 34.7 & 38.7 & 31.3 & -6.6 \\
\hline 2011 & 22.5 & 24.9 & 20.3 & -15.3 \\
\hline 2012 & 23.9 & 26.7 & 22.7 & -9.2 \\
\hline 2013 & 22.8 & 23.4 & 21.8 & -7.8 \\
\hline 2014 & 24.6 & 24.7 & 20.4 & -8.4 \\
\hline 2015 & 22.7 & 22.9 & 22.5 & -9.6 \\
\hline 2016 & -6.8 & -5.5 & -7.7 & 5.6 \\
\hline 2017 & 11.4 & 15.9 & 7.9 & 8.6 \\
\hline
\end{tabular}

Table 3 shows that during the period of 2006-2015 the exchange rate of RMB in China is rising rapidly and continuously but China's import and export trade is still able to grow at a faster rate, and there is no significant change in the overall trend.In addition, China's trade surplus is declining year by year, and China's balance of payments is gradually becoming more balanced.[5]

\subsubsection{Changes in the ratio of dependence on foreign trade}

The ratio of dependence on foreign trade directly reflects the degree of a country's outward orientation and its participation in international division.It is an important index to analyze the influence and dependence of a country's foreign trade activities on its economic development.

Table 4 Percentage of change in foreign trade dependence(\%)

\begin{tabular}{|l|l|l|l|l|l|l|}
\hline Year & 2006 & 2007 & 2008 & 2009 & 2010 & 2011 \\
\hline foreign trade dependence & 40.8 & 43 & 48.9 & 33.95 & 45.66 & 44.39 \\
\hline Year & 2012 & 2013 & 2014 & 2015 & 2016 & 2017 \\
\hline foreign trade dependence & 48.23 & 44.95 & 40.54 & 41.5 & 36 & 32 \\
\hline
\end{tabular}

As shown in Table 4, in addition to the fluctuation of foreign trade dependence caused by the world financial crisis in 2009, China's foreign trade dependence has gradually declined in the six years from 2010 to 2015 [6].This shows that after the exchange rate reform in 2005, the appreciation of the RMB exchange rate has improved China's economic growth model, adjusted China's industrial structure, and played a vital role in the sound and rapid development of China's economy.

\subsubsection{Changes in trade patterns}

Table 5 shows that China's trade mode has been developing and optimizing in the past ten years. 
Because of the appreciation of RMB exchange rate, the proportion of general trade is increasing, and the proportion of processing trade is declining. The main reason for this phenomenon is that in recent years, China's investment in fixed assets continues to grow at a high speed, resulting in excess capacity higher than the effective domestic demand. In order to transfer these excess capacity, China's general trade exports continue to grow.[7]

Table 5 The proportion of processing trade to China's total import and export volume

\begin{tabular}{|c|c|c|c|c|c|c|}
\hline Year & $\begin{array}{c}\text { Export } \\
\text { volume }\end{array}$ & $\begin{array}{c}\text { The processing trade } \\
\text { exports volume }\end{array}$ & $\begin{array}{c}\text { Percentage } \\
(\%)\end{array}$ & $\begin{array}{c}\text { Import } \\
\text { volume }\end{array}$ & $\begin{array}{c}\text { The processing trade } \\
\text { imports volume }\end{array}$ & $\begin{array}{c}\text { Percentage } \\
(\%)\end{array}$ \\
\hline 2006 & 9689 & 5111 & 52.8 & 7920 & 3209 & 40.5 \\
\hline 2007 & 12179 & 6180 & 50.7 & 9561 & 3691 & 38.6 \\
\hline 2008 & 14290 & 6749 & 47.2 & 11329 & 3779 & 33.3 \\
\hline 2009 & 12020 & 5869 & 48.8 & 10062 & 3218 & 32.0 \\
\hline 2010 & 15780 & 7398 & 46.9 & 13951 & 4167 & 29.9 \\
\hline 2011 & 18965 & 8349 & 44.0 & 17440 & 4689 & 26.9 \\
\hline 2012 & 21324 & 9147 & 42.9 & 19574 & 5024 & 25.7 \\
\hline 2013 & 23986 & 9981 & 41.6 & 19487 & 4583 & 23.5 \\
\hline 2014 & 26774 & 10782 & 40.2 & 19706 & 4175 & 21.1 \\
\hline 2015 & 29571 & 11436 & 38.7 & 19163 & 4681 & 24.4 \\
\hline 2016 & 20976 & 8456 & 40.3 & 15879 & 3421 & 21.5 \\
\hline 2017 & 22635 & 9345 & 41.3 & 18410 & 5452 & 29.6 \\
\hline
\end{tabular}

\subsection{The impact of RMB exchange rate appreciation on China's foreign trade}

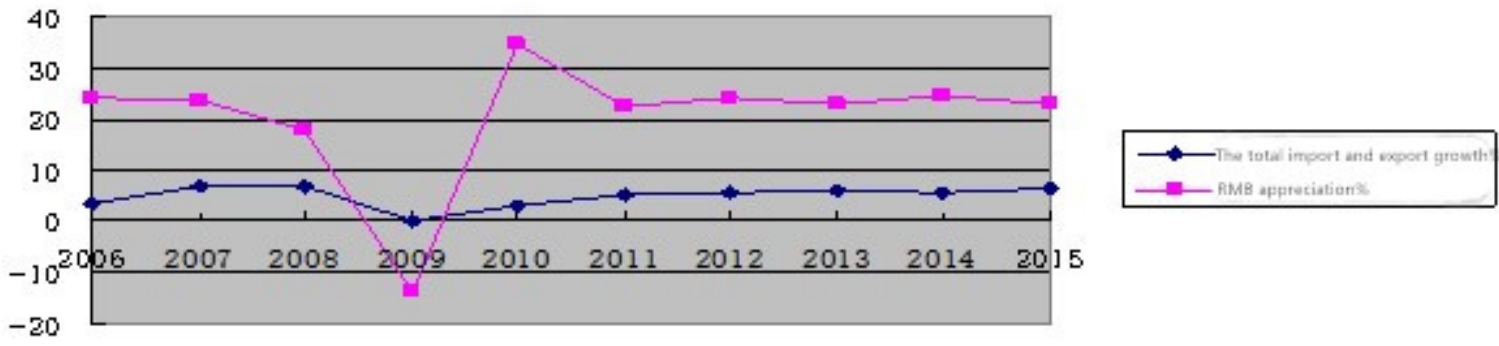

Fig. 1 China's total import and export volume and the RMB appreciation between 2006 and 2015

Figure 1 shows that except for 2009, the impact of RMB exchange rate appreciation on China's import and export trade is not very obvious.However, from a qualitative point of view, the appreciation of the RMB exchange rate has affected the business activities of micro-managers and the development of macro-economy, resulting in positive and negative effects.

\subsubsection{Negative effects}

(1) Weaken the macroeconomic regulation and control effect, and affect the stability of financial market. 
Since the exchange rate reform in 2005, the RMB has continued to appreciate steadily, which is basically in line with the expectations of the market for the RMB value. Under the expectation of a small and sustained appreciation of the RMB, a large number of foreign liquidity funds attempt to enter China's financial market for speculative activities.This led to excess liquidity in the domestic market, asset pricing soared, and gradually formed a bubble economy.[8]At the same time, the influx of a large number of external speculative funds led to the growth of foreign exchange accounts, the central bank needs to put more money to hedge these foreign exchange accounts, making domestic inflation pressure increased, increasing the difficulty of central bank macro-control.

(2) The ability to attract foreign investment has declined and domestic employment pressure has increased

First, RMB appreciation has increased the cost of foreign investors' investment in China, which has led to a gradual slowdown in the growth rate of foreign investment.Second, it has led to the rise of domestic labor prices, and the advantage of cheap labor is decreasing.Finally,it has increased imports, impacting domestic related industries and resulting in a reduction in the production scale of domestic enterprises.[9]

All these changes have reduced the employment opportunities and increased the employment pressure in China.

\subsubsection{Positive impact}

(1) Adjusting the balance of payments and improving the terms of trade

With the continuous appreciation of the RMB, China's trade surplus is gradually decreasing, which helps to reduce trade disputes, strengthen international relations, and is conducive to the sustained, stable and rapid development of China's economy and the promotion of its international status.

(2) Stimulating imports

To a great extent, the appreciation of RMB has directly reduced the import cost of our importers and increased the import volume of our importers.For Chinese residents, this means that the price of foreign commodities has fallen, which is conducive to the purchase of foreign commodities and the use of foreign services; for Chinese enterprises, this means that the cost of imported raw materials and technical equipment has been reduced, which is conducive to the enterprises themselves to obtain greater profits.

(3) Conducive to internationalization strategy of enterprises

The continuous appreciation of RMB reduces the investment cost of Chinese domestic enterprises overseas, which is conducive to further expanding the scale of overseas investment, making full use of abundant overseas resources and advanced technology to develop themselves, thus helping China to reduce the pressure on domestic foreign reserves.[10]

(4) Accelerating the internationalization of RMB

Recently China has gradually opened its cross-border RMB settlement service which can increase the international influence of RMB as an international currency. In addition, the continuous $\mathrm{RMB}$ appreciation also makes foreigners keep increasing their holdings of the RMB, which to a certain extent has promoted the process of internationalization of the RMB.

\section{Suggestions}

\subsection{Macro-strategies}

(1) Expand domestic demand market and reduce external dependence. 
With regard to the current development of our country, China's economy still has a high degree of dependence on foreign trade. On the one hand, expanding the domestic demand market can reduce the trade surplus between China and other trading partners, thereby reducing the foreign exchange account caused by it and reducing the pressure of RMB appreciation.On the one hand, expanding the domestic demand market can reduce the trade surplus between China and other trading partners, thereby reducing the foreign exchange account caused by it and reducing the pressure of RMB appreciation.

(2) Improve the RMB exchange rate formation mechanism

The rise of the RMB exchange rate has a huge impact on China's export oriented enterprises. On the basis of guaranteeing macroeconomic security, the state should relax its control and restriction on foreign exchange, enlarge the floating range of RMB exchange rate, and truly form a market and supply-demand oriented exchange rate formation mechanism.

\subsection{Micro-strategies}

\subsubsection{Enhancing policy publicity and guidance for export enterprises}

At present, China is in the stage of rapid economic development, most small and medium-sized enterprises do not know how to face the pressure of RMB appreciation. Enterprises should organize relevant scholars to guide SMEs in exchange rate sensitive industries in their transformation.At the same time, we can guide enterprises to avoid exchange rate risk from the perspective of public opinion by means of propaganda and training of exchange rate risk aversion.

\subsubsection{Enterprises should enhance their ability of risk awareness and risk aversion.}

The managed floating exchange rate regime has increased the operational risks of Chinese enterprises. Therefore, enterprises should take corresponding measures to avoid exchange rate risks. The specific measures are listed in Table 6.

Table 6 Six measures for enterprises to avoid exchange rate risks

\begin{tabular}{|c|c|}
\hline 1 & Spread risk with advantageous valuation currencies \\
\hline 2 & $\begin{array}{r}\text { Reduce losses by increasing the amount of advance payment. } \\
\text { launched by commercial banks }\end{array}$ \\
\hline 3 & $\begin{array}{r}\text { Guarantee the value and increase of large amount of funds through } \\
\text { foreign exchange structured deposits }\end{array}$ \\
\hline 4 & Increase cross border trade fund settlement \\
\hline 5 & Speed up foreign exchange settlement \\
\hline
\end{tabular}

\subsubsection{The trade associations should play an active role}

Industry associations should formulate corresponding industry standards to avoid disorderly competition at low prices, which is important for coordinating market prices, guiding the normal operation of domestic enterprises and protecting the interests of domestic industries

\section{Conclusion}

Under the background of RMB internationalization, exchange rate has a very important impact 
on China's economic growth, import and export trade and foreign direct investment. The change of exchange rate has a direct impact on the relative price and foreign trade of a country's import and export commodities.

Through theoretical analysis and data analysis, this paper studies the positive and negative effects of RMB appreciation on import and export trade since the RMB exchange reform, and puts forward suggestions and suggestions from the macro and micro levels. The specific conclusions are as follows: Firstly, China's import and export trade is affected by many factors, such as macro-control, tax policy and industrial policy. The impact of the change of the single RMB exchange rate on China's import and export trade is limited. China's import and export trade still maintains a high growth rate. Faced with the impact of exchange rate rise on China's import and export, we should adopt a positive attitude to cope with and avoid disadvantages, avoid the short-term impact of RMB exchange rate appreciation on China's long-term import and export enterprises with a fixed exchange rate. In the long run, the appreciation of RMB exchange rate can promote the integration and optimization of China's industrial structure, enhance the comprehensive strength and international influence of Chinese enterprises, and is conducive to the long-term development of China's economy.

From a practical point of view, first of all, through theoretical and empirical analysis, we can more intuitively understand the impact of RMB appreciation on economic growth and the degree of impact, and promote the positive role of exchange rate on macroeconomic development. Secondly, through the theoretical and Empirical Study of macroeconomic growth and exchange rate fluctuation, it can provide decision-making for macroeconomic management departments, and also can provide reference for determining the level of RMB exchange rate, so as to better adjust the fluctuation of RMB exchange rate.

\section{References}

[1] Krugman Paul. Differences in Income Elasticities and Trends in Real Exchange Rates [J]. European Economic Review, 1989(5):131-146

[2] SaangJoon Baak. The Bilateral Real Exchange Rates and Trade between China and the U. S.[J]. China Economic Review, 2008(9):117-127

[3] Choudhry Taufiq. Exchange Rate Volatility and the United States Exports: Evidence from Canada and Japan [J]. Journal of the Japanese and International Economies, 2005(3):51-71

[4] A Simple Trade Model with an Optimal Exchange Rate Motivated by Discussion of a Renminbi Float [J]. Hui Huang, Yiming Wang, John Whalley,Shunming Zhang. Modern Economy. 2012

[5] Chen Jianqi. Revaluation of the impact of RMB exchange rate appreciation on China's economy based on em pirical evidence since the exchange rate reform in 2005 [J]. World Economic Research, 2011 (12): 44-50 + 85.

[6] Li Siyu. The impact of RMB exchange rate appreciation on Zhejiang's foreign trade [J]. era finance, 2016 (15): $80-81$

[7] Su Jing. Research on the influence of RMB exchange rate appreciation on China's export comparative advantage [D]. Shanghai Jiao Tong University, 2014.

[8]Chen Bingcai, Xing Houyuan. Trade, Investment and RMB Internationalization - International Financial Trends and RMB Exchange Rate Policy [M]. Beijing: China Financial Publishing House, 2008

[9] Li Yining. China's foreign economy and balance of payments [M]. Beijing: Beijing International Culture Publishing Company, 1991

[10] Wu Xiaoling. China foreign exchange management [M]. Beijing: China finance press, 2001 